\title{
The Analysis Of Educational Thought According To Ibn Sina And Its Relevance In Islamic Education In The Modern Era
}

\author{
Yasmansyah $^{1)}$, Lainah $^{2}$, Wedra Aprison ${ }^{3)}$ \\ 1,2,3) S3 Program studi PAI FTIK IAIN Bukittinggi \\ *Coresponding Author \\ Email : $\underline{\text { Yasmansyahsagmpd@gmail.com }}$
}

\begin{abstract}
This study aims to analyze the educational thought according to Ibn Sina and its relevance in Islamic Education in the modern era. The method used in this study uses a library method or approach (library research). Data obtained through literature study. The results showededucational thought of Ibn Sina are the concept of educational goals, the concept of learning methods, the concept of the educational curriculum. There were seven educational methods offered by Ibn Sina, namely: (1) Talqin, this method is used in reading the Koran by hearing the reading of the Koran to students in stages, (2) Demonstration, method this is used in writing lessons, (3) modeling and habituation, this method is used in learning morals, (4) Discussion, this method is carried out by the teacher describing a problem in a lesson to be solved together by students, (5) Apprenticeship, this method is used so that students can combine theory and practice, where students are asked to practice the theory they have obtained, (6) Assignment, this method is done by the teacher preparing and giving modules to students to learn, and (7) targhib and tarhib, this method in modern education is known as reward (reward) and punishment (punishment). The sources of Islam and Islamic education are the same, namely the most important, the Koran and the Sunnah of the Prophet. Therefore, Ibn Sina's conception of education is still very relevant when applied today.
\end{abstract}

Keywords: Educational Thought, Ibn Sina, Islamic Education, Modern Era.

\section{INTRODUCTION}

Ibn Sina (Avicenna) is one of the foremost philosophers in the Medieval Hellenistic Islamic tradition that also includes al-Farabi and Ibn Rushd His philosophical theory is a comprehensive, detailed and rationalistic account of the nature of God and Being, in which he finds a systematic place for the corporeal world, spirit, insight, and the varieties of logical thought including dialectic, rhetoric and poetry.

The Islamic education philosophy must be an Islamic philosophy and not just philosophy, even though the nature of Islamic philosophy itself is philosophy. Islamic education philosophy is an ontological study of Islamic philosophy. Its rational derivation is Islamic philosophy, Islamic education philosophy, then Islamic education science. So epistemologically, Islamic education science should be a product of the Islamic education philosophy. The Islamic education philosophy product is Islamic education science. Islamic education science is a system built on its constituent elements. The elements are educators, students, curriculum, 
learning process, and evaluation. If it is consistent with the epistemological process, elements in islamic education science should have a philosophical basis, namely Islamic philosophy.

Al-Abrasy (1994) said that Ibn Sina is a philosopher Muslim who is famous in the world. His thoughts can be seen and found from various works that made, and has been translated into in multiple languages. Name of Ibn Sina more known when there are other people which discusses his thoughts. One of them is Prof. Dr. Muhammad Athiyah Al Abrasy with title AlTarbiyah Al-Islamiyah wa Falalatifuha, which translates to in Indonesian becomes "Ibn Sina's Main Thoughts on Education" by Syamsuddin Asyrafi, Ahmad Warid Khan and Nizar Ali.

Central to Ibn Sina's philosophy is his concept of reality and reasoning. Reason, in his scheme, can allow progress through various levels of understanding and can finally lead to God, the ultimate truth. He stresses the importance of gaining knowledge, and develops a theory of knowledge based on four faculties: sense perception, retention, imagination and estimation. Imagination has the principal role in intellection, as it can compare and construct images which give it access to universals. Again the ultimate object of knowledge is God, the pure intellect.

In metaphysics, Ibn Sina makes a distinction between essence and existence; essence considers only the nature of things, and should be considered apart from their mental and physical realization. This distinction applies to all things except God, whom Ibn Sina identifies as the first cause and therefore both essence and existence. He also argued that the soul is incorporeal and cannot be destroyed. The soul, in his view, is an agent with choice in this world between good and evil, which in turn leads to reward or punishment.

Reference has sometimes been made to Ibn Sina's supposed mysticism, but this would appear to be based on a misreading by Western philosophers of parts of his work. As one of the most important practitioners of philosophy, Ibn Sina exercised a strong influence over both other Islamic philosophers and medieval Europe. His work was one of the main targets of alGhazali's attack on Hellenistic influences in Islam. In Latin translations, his works influenced many Christian philosophers, most notably Thomas Aquinas.

According to Ibn Sina, the purpose of education must be directed at developing all the potential that a person has towards his perfect development, namely physical, intellectual, and moral development. Apart from that, according to him, the purpose of education should be directed at the effort to prepare a person so that they can live in society together by doing the work or expertise they choose according to their talents, readiness, tendencies, and potential.

According to Fatkhur Roji (2020) that the internal challenges and problems of postglobalization in Islamic education today and in the future, in general, are as follows: First, the type of education chosen and implemented, with changes in educational policies and politics. Second, the question of identity in certain Islamic institutions. And third, institutional strengthening and management of an Islamic educational institution. Concept in Islamic Education in the millennial era, with the results of the study stated that in relation to Islamic education, in Ibn Sina's view, education should aim to explore and develop the potential of students. The development of this potential includes the development of physical, intellectual, and moral character in the context of realizing human beings.

\section{RESEARCH METHODS}

The research method is literature review or literature study, which contains theories relevant to research problems. The problem in this research is to find out educational thought of Ibn Sina, The concept of Islamic Education, The Relevance Islamic Education in the Modern Era. In this section, Ibn Sina's concepts and theories used is carried out based on the available 
literature, especially from articles published in various scientific journals. Literature review serves to build concepts or theories that form the basis of studies in research. Literature review or literature study is an activity that is required in research, especially academic research whose main purpose is to develop theoretical aspects as well as aspects of practical benefits (Mestika Zed, 2004).

\section{RESULTS AND DISCUSSION}

\section{Educational Thought of Ibn Sina}

Raghib As-Sirjani (2012) said that There are several points of Ibn Sina's philosophical thoughts in the field of education:

First, the concept of educational goals. Ibn Sina explained that the purpose of education has a normative function, namely the goal as a determinant of the course of the educational process, the goal as a stimulant to the educational process, and the goal as a value and will be the start of the educational process. Educational objectives according to Ibn Sina need to be directed at physical, intellectual development, and manners so that students can develop perfectly. Ibnu Sina also said that the goals of education also need to be adjusted to the talents, tendencies and potential of students so that they can live in society with their expertise. From the explanation above, in general the purpose of education according to Ibn Sina is the achievement of human beings, besides that the purpose of education is also directed so that humans can carry out the function of the caliph in society properly. As for specifically, Ibn Sina has classified the goals of education in terms of physical aspects, character, and skills. The purpose of character education is directed towards the formation of students who have good morals that can be applied to everyday life. Here the students' feelings are also developed through art education. The goal of physical education is to achieve the happiness of students through physical activities and physical development, such as sports, eating, drinking, sleeping, and maintaining cleanliness so that students' physical and brain intelligence can grow and develop optimally.

Second, the concept of the educational curriculum. Ibnu Sina classifies the curriculum based on the age level of students, namely: (1) Age 3-5 years, at this age level the subjects given are sports, character, cleanliness, sound arts, and arts, (2) Ages 6-14 years, at this age level the curriculum includes reading and memorizing lessons on the Koran, religion, poetry, and sports, (3) Ages 14 and over, at this age the subjects given are quite a lot and need to be selected according to interests. and the talents of students. Ibn Sina also classifies subjects into two, namely subjects that enter theoretical science and subjects that enter practical science. Theoretical sciences include tabi'i science, mathematics, divinity. While practical science includes: moral science, household sciences, and political science.

From the explanation above, the concept of Ibn Sina's curriculum has the following characteristics: (1) The preparation of the curriculum that was carried out by Ibn Sina pays close attention to the psychology of students, where the curriculum he compiled is based on the stages of development of students, (2) The curriculum concept of Ibn Sina tries develop physical, moral and intellectual aspects of students in a balanced manner based on their age development stage, (3) Are functional pragmatic, where the curriculum is directed to be able to develop the potential of students so as to produce graduates who can meet the needs of society or the market with their areas of expertise, (4) The concept of curriculum is based on the Koran and Sunnah so that students have faith, knowledge, and charity in an integrated manner, and (5) Based on morals, the curriculum is prepared to pay close attention to moral education.

Third, the concept of learning methods. Learning methods have an important role in achieving learning objectives. The learning method can be interpreted as a set of ways, techniques to 
achieve a competency or goal that has been formulated in learning. Ibn Sina views that the use of learning methods must be adjusted to the characteristics of the learning material so as not to lose its relevance. There are several educational methods offered by Ibn Sina.

Abuddin Nata said there were seven educational methods offered by Ibn Sina, namely: (1) Talqin, this method is used in reading the Koran by hearing the reading of the Koran to students in stages, (2) Demonstration, method this is used in writing lessons. When the teacher uses this method, the teacher first gives an example of written letters in front of the students and then the students imitate it, (3) modeling and habituation, this method is used in learning morals. This method departs from the view that children in thabi'iyah have a tendency to imitate something they see, feel, and hear, (4) Discussion, this method is carried out by the teacher describing a problem in a lesson to be solved together by students. This method is used to teach theoreticalrational knowledge, (5) Apprenticeship, this method is used so that students can combine theory and practice, where students are asked to practice the theory they have obtained. This method will make students proficient in their field of science, (6) Assignment, this method is done by the teacher preparing and giving modules to students to learn, (7) targhib and tarhib, this method in modern education is known as reward (reward) and punishment (punishment).

\section{The concept of Islamic Education according to Ibn Sina}

The objectives of education according to Ibn Sina, namely: First Directed to the development of all the potential that a person has towards the perfect development of both physical, intellectual and moral development. Second, Directed at efforts in order to prepare someone to live together in society by doing the work or expertise he chooses according to his talents, readiness, tendencies and potentials. Meanwhile, the objective of physical education that should not be abandoned is physical guidance and everything related to it such as exercise, sleeping, drinking, and maintaining cleanliness. With physical education, it is hoped that the physical growth of students who are intelligent in their brains will be fostered. Through character education, children are expected to familiarize themselves with manners in their daily life interactions. As for art education, it is hoped that a child can sharpen his feelings and increase his imagination (Rudi Ahmad, 2018).

Ibn Sina then divides lessons into those that are theoretical and lessons that are practical or applied knowledge. Theoretical Subjects According to Ibn Sina, theoretical subjects can be divided into three more, namely: Tabi'i science which is categorized as science which is in the lower order, Mathematics which is placed in the middle order, Divine science which is placed as the order the highest. Practical Subjects Practical subjects are divided into three parts: the first consists of knowledge that aims to form noble human morals and actions, so that they can lead to the happiness of living in the world and the hereafter. The second consists of knowledge that seeks to explain the procedures for managing domestic life and the pattern of good relationships between husband and wife, parents and their children, employers and their assistants. The third is the study of politics, leadership, the state and society, or vice versa. According to Ibn Sina's explanation, the curriculum is based on the level of age development of students, such as sports, character, cleanliness, sound arts and arts, these are all for children aged 3 to 5 years. Regarding sports subjects that are influenced by psychological views that can be seen from the development of age and talent, so that it can be seen which ones are more trained in sports that require strong physical and skill and which are classified as light, fast, slow and so on. . Furthermore, the curriculum for children aged 6 to 14 years includes reading lessons, memorizing the Koran, religious lessons, poetry, and sports. The curriculum for ages 14 and over is divided into theoretical and practical subjects. As for the theoretical ones, they are physics, mathematics, divinity. Subjects that are practical in nature are the science of morals 
which studies how to manage a person's behavior, both household management, political science, trade, and professional science.

The concept of Islamic education's Ibn Sina used the methods. There are the talqin method, demonstrations, habituation and role models, discussions, internships, and assignments. The talqin method: The talqin method is used in teaching reading the Koran, the demonstration method: According to Ibn Sina, the demonstration method can be used in practical learning, such as how to teach writing, the method of habituation and exemplary: Ibn Sina argues that habituation is wrong. one of the most effective teaching methods, especially in teaching morals. Discussion method: The method of discussion can be done by presenting a lesson in which students are faced with a problem which can be a problematic question to be discussed and solved together. Ibn Sina uses this method to teach rational and theoretical knowledge. Apprenticeship method: Ibn Sina has used this method in his teaching activities. Ibn Sina's students studying medicine are encouraged to combine theory and practice, Assignment method: This assignment method was once used by Ibn Sina by compiling a number of modules or texts then conveying them to his students to study, Targhib and tarhib methods: Targhib or rewards, prizes , appreciation or payoff as good motivation.

Ibn Sina's thought about a good teacher is a teacher who is intelligent, religious, knows how to educate morals, is proficient in educating children, has a calm appearance, is far from making fun of and messing around in front of his students, not surly, manners, clean and pure chaste. Then a teacher according to Ibn Sina should be from men who are respectable and outstanding in character, intelligent, thorough, patient, painstaking in guiding children, fair, efficient in the use of time, fond of associating with children, not hard-hearted and always self-decorating. Ibn Sina's thoughts about education are related to his thoughts on the philosophy of science. According to Ibn Sina, knowledge is divided into two, namely impermanent knowledge and eternal knowledge (wisdom). Eternal knowledge in terms of its role as a tool can be called logic. But based on its objectives, science can be divided into practical and theoretical sciences. Theoretical sciences such as natural science, mathematics, divinity and Kulli science. Whereas practical knowledge is the science of morals, the science of house management, the science of city management and the science of prophets (shari'ah).

\section{The Relevance Islamic Education in the Modern Era}

Islamic education is an absolute necessity in order to practice Islam as desired by Allah. Based on this meaning, Islamic education prepares humans to carry out the mandate assigned to them. This means that the sources of Islam and Islamic education are the same, namely the most important, the Koran and the Sunnah of the Prophet. Judging from its basic and operational concepts and implementation practices, Islamic education basically contains three definitions: Islamic education is education according to Islam or Islamic education, namely education that is understood and developed from the teachings and fundamental values contained in the source basically, namely the Koran and al-Sunnah.

In the above definition, Islamic education can take the form of educational ideas and theories that are self-based or built and developed from these basic sources or originating from the Islamic spirit. Islamic education is Islamic education or Islamic religious education, which is an effort to educate Islam or its teachings and values, so that it becomes a way of life (view of life) and one's attitude in life.

Ibn Sina's educational thought in his practical philosophy (practical science) includes moral science, knowledge of household affairs, politics and shari'ah. This work is principally concerned with how to organize and guide humans in various stages and systems. The discussion begins with individual education. That is how a person controls oneself (morals). Then proceed with guidance to the family (takbiralmanzil), then extend to society (tadbir al- 
madinat) and finally to all mankind. So according to Ibn Sina, the education given by the prophet is essentially human education. Here it can be seen that Ibn Sina's educational thinking is comprehensive. Meanwhile, Ibn Sina's views in the political field can hardly be separated from his views in the field of religion, because according to him almost all branches of Islamic science are related to politics, this science then he divides into four branches, namely the science of morals, the science of how to manage the household, the science of constitutional and prophetic science. Political science is also included in the science of education, because the science of education is the science that is at the forefront of preparing cadres who are ready to carry out government tasks. In his educational thinking, Ibn Sina has also described educational psychology. This can be seen from his description of the relationship between children's education and the level of age, willingness and talent of the child. By knowing the background of the level of development, talent and willingness of the child, the guidance given to children will be more successful. According to Ibn Sina, there is a tendency for humans to choose different jobs because in humans there are hidden factors that are difficult to understand and understand and difficult to , measure. With this view, it can be seen that in his educational thinking he has pioneered the existence of Individual Differences as is known in the modern world of education today (Istikhori, 2017).

So, based on the definition of the law above, Ibn Sina's conception of education is still very relevant when applied today. Bearing in mind, the education applied by Ibn Sina is in accordance with the needs of the present era, even in leading schools today there are still many that carry the educational model as applied by Ibn Sina, starting from his educational goals to the criteria of a teacher expected in Islamic education.

\section{CONCLUSION}

There are several learning methods in Ibn Sina's educational concept, including the talqin method, demonstration, example and habituation, discussion, internship, assignment, tarhib, and targhib. Teachers in Ibn Sina's view must be able to be role models for their students. According to Ibn Sina, the qualities that must be possessed by a teacher are having a sound mind, having a strong religion, having noble character, understanding students, being authoritative, having a strong personality, broad-minded, well-spoken, smart, educated, goodlooking. kind and attractive, have a sincere heart.

Although Ibn Sina's thoughts on education were not born in modern times, his thoughts are still relevant to today's life. the values of Islamic teachings that are sourced from the Qur'an and Sunnah.

\section{REFERENCES}

Anshori, Sodiq. (2016). Strategi pembelajaran di era digital (tantangan profesionalisme guru di era digital). Prosiding Temu Ilmiah Nasional Guru (TING) VIII. Universitas Terbuka Convention Center, 26 November 2016. 194-202.

Birdsall, W. F. (2009). Serving Diverse Knowledge Systems in Academia. Library and Information Practice and Research. 4 (1) : 1-7. 
Byrne, W. I. O., Radakovic, N., Hunter, T., Fox, M., Kern, R., Parnell, S. (2018). Designing Spaces for Creativity and Divergent Thinking: Pre-Service Teachers Creating Stop Motion Animation on Tablets. International Journal of Education in Mathematics, Science and Technology. 6 (2) : 182-199.

Calderón, A., Meroño, L., \& MacPhail, A. (2020). A student-centred digital technology approach: The relationship between intrinsic motivation, learning climate and academic achievement of physical education pre-service teachers. European Physical Education Review. 26 (1) : 241-262.

Casey, A., Goodyear, V. A., \& Armour, K. M. (2017). Rethinking the relationship between pedagogy, technology and learning in health and physical education. Sport, Education and Society. 22 (2) : 288- 304.

Cheok, M. L., Wong, S. L., Mohd Ayub, A. F., \& Mahmud, R. (2016). Understanding Teacher Educators' Beliefs and Use of Information and Communication Technologies in Teacher Training Institute. In Envisioning the Future of Online Learning (pp. 11-21). Springer Singapore.

Cutajar, Maria. (2019). Teaching using digital technologies: Transmission or participation?. Education Sciences. 9 (3) : 1-13.

Dinc, E. (2019). Prospective Teachers' Perceptions of Barriers to Technology Integration in Education. Contemporary Educational Technology. 10 (4) : 381- 398.

Ekawati, N. E. (2018). Application of Blended Learning with Edmodo Application Based on PDEODE Learning Strategy to Increase Student Learning Achievement. Jurnal Ilmiah Pendidikan MIPA. 8 (1) : 7-16.

Gallardo-echenique, E., Bullen, M., \& Molias, L. M. (2016). Student Communication and Study Habits of First-year University Students in the Digital Era. Canadian Journal of Learning and Technology. 42 (1) : 1-21.

Ghotbifar, Fereshteh., Marjani, Mohammad Reza Marjani, \& Ramzani, Abbas. (2017). Identifying And Assessing The Factors Affecting Skill Gap In Digital Marketing In Communication Industry Companies. Independent Journal of Management \& Production. $8(1): 1-14$.

Goos, M. (2010) Using technology to support effective mathematics teaching and learning: What counts? Research Conference on Teaching Mathematics? Make it count: What research tells us about effective mathematics teaching and learning. Research Conference 15-17 August 2010 Crown Conference Centre Melbourne.

Habibullah, H., \& Bulan, N. (2017). Pembelajaran Matematika di Era Milenium Ke-3. In Seminar Matematika dan Pendidikan Matematika UNY. M-49 : 329-334.

Harrison, T. R., \& Lee, H. S. (2018). iPads in the Mathematics Classroom: Developing Criteria for Selecting Appropriate Learning Apps. International Journal of Education in Mathematics. 6 (2) : 155-172.

Heflin, H., Shewmaker, J., \& Nguyen, J. (2017). Impact of mobile technology on student attitudes, engagement, and learning. Computers \& Education. 107, 91-99. 
Henderson, M., Selwyn, N., \& Aston, R. (2017). What works and why? Student perceptions of 'useful' digital technology in university teaching and learning. Studies in Higher Education. 42 (8) : 1567-1579.

Hoyles, C., \& Lagrange, J.-B. (Eds.). (2010). Mathematics education and technologyRethinking the terrain. New York, NY/Berlin, Germany: Springer.

Isnaini Utami, N., Holisin, I., \& Mursyidah, H. (2018). The Development of Engklek Geometry Learning Media to Preserve Traditional Game. Jurnal Ilmiah Pendidikan MIPA. 8 (3) : 211-224.

Jose Mendoza, D., \& Isaac Mendoza, D. (2018). Information and Communication Technologies as a Didactic Tool for the Construction of Meaningful Learning in the Area of Mathematics. International Electronic Journal of Mathematics Education. 13 (3) :261-271.

Jotikabukkana, Phat., Sornlertlamvanich, Virach., \& Manabu, Okumura. (2016). Social Media Text Classification by Enhancing Well-Formed Text Trained Model. Journal of ICT Research and Applications. 10( 2) : 177-196.

Lackovic, N., Kerry, R., Lowe, R., \& Lowe, T. (2017). Being knowledge, power and profession subordinates: Students' perceptions of Twitter for learning. The Internet and Higher Education. 33 : 41-48.

Lee, Y., Capraro, R. M., \& Capraro, M. M. (2018). Mathematics Teachers' Subject Matter Knowledge and Pedagogical Content Knowledge in Problem Posing. International Electronic Journal of Mathematics Education. 13 (2) : 75-90.

Lee, Y. J. (2019). Integrating multimodal technologies with VARK strategies for learning and teaching EFL presentation: An investigation into learners' achievements and perceptions of the learning process. Australian Journal of Applied Linguistics. 2 (1) : 17-31.

Maulana Yusup, A. A. (2017). Meningkatkan Hasil Belajar Matematika Melalui Penerapan Metode Pembelajaran Kooperatif. Formatif: Jurnal Ilmiah Pendidikan MIPA. 7 (2) : 124-129.

Mioduser, D., Nachmias, R., \& ForkoshBaruch, A. (2008). New Literacies for the Knowladge Society. International Handbook of Information Technology in Primary and Secondary Education (pp. 23-42) : Springer US.

Nurjanah, N, Herlambang, Y, T, Gandana, G \& Hendrawan, B. (2020). Regional Language Education In The Era Of The Industrial Revolution Era 4.0: An Idea About Education In The Techno Pedagogy Perspective. Journal of Physics: Conference Series. Vol 1477. 15

Olive, J., \& Makar, K., with V. Hoyos, L. K. Kor, O. Kosheleva, \& R. Straesser (2010). Mathematical knowledge and practices resulting from access to digital technologies. In C. Hoyles \& J. Lagrange (Eds.), Mathematics education and technology - Rethinking the terrain. The 17th ICMI Study (pp. 133-177). New York: Springer. 
Email : editorijhess@gmail.com

Prestridge, S., \& De Aldama, C. (2016). A Classification Framework for Exploring Technology-Enabled Practice-FrameTEP. Journal of Educational Computing Research. 54 (7) : 901-921.

Putrawangsa, S., \& Hasanah, U. (2018). Integrasi Teknologi Digital Dalam Pembelajaran Di Era Industri 4 . 0 (Kajian dari Perspektif Pembelajaran Matematika). Jurnal Pemikiran Dan Penelitian Pendidikan. 16 (1) : 42-54.

Radhy, Z. H. (2019). Application of Multiply Regression Linear Model and New Technology Method in Estimating. Learning and Education of Students. 14 (1) : 87-90.

Rangkuti, A. N. (2014). Tantangan dan peluang pembelajaran matematika. Jurnal Pendidikan Matematika. II (01) : 1-13.

Smite, Rasa. (2013). Creative Network Communities in the Translocal Space of Digital Networks. Human Technology. 9 (1) : 4-21.

Sulistyaningsih, Dwi., Purnomo, \& Aziz, Abdul. (2019). Development of Learning Design for Mathematics Manipulatives Learning Based on E-learning and Character Building. International Electronic Journal of Mathematics Education. 14 (1) : 197-205.

Supardi, S. (2015). Peran Berpikir Kreatif Dalam Proses. Jurnal Formatif. 2 (3) : 248-262.

Tatan Z M, T., \& Sumiati, T. (2011). Pengaruh Penggunaan Media Belajar dan Minat Belajar terhadap Hasil Belajar Matematika. Formatif: Jurnal Ilmiah Pendidikan MIPA. 1 (1) : 70-81.

Wartomo. (2016). Peran Guru Dalam Pembelajaran Era Digital. Prosiding Temu Ilmiah Nasional Guru (TING) VIII. Universitas Terbuka Convention Center, 26 November 2016. pp : 265-275.

Xiaonan, X. (2017). Dialectical Thinking and Exploratory Method in College Math Teaching. Proceedings of the 2017 3rd International Conference on Social Science and Higher Education. September 2017. 99 : 1-2.

Zed, Mestika. (2014). Metode Penelitian Kepustakaan (Cetakan ke-3). Jakarta : Yayasan Pustaka Obor Indonesia. 